This is the accepted version of an article that will be published by Cambridge University Press in The Journal of African History: https://www.cambridge.org/core/journals/journal-of-african-history/allissues

Accepted version downloaded from SOAS Research Online: http://eprints.soas.ac.uk/25963/

\title{
Poverty and respectability in early twentieth-century Cape Town ${ }^{1}$ Wayne Dooling \\ (School of Oriental and African Studies, University of London)
}

\begin{abstract}
Despite the challenges of overwhelming poverty, characterised by poor housing, ill health and shortened lifespans, Cape Town's black population of the early twentieth century actively pursued lifestyles that might be described as respectable. But respectability was expensive and poverty stood in the way of some of its most essential elements: cleanliness, sexual restraint, sobriety, and the creation of nuclear and gendered households. Black respectability, therefore, could not simply replicate that of the dominant white bourgeoisie. Most challenging was the development of rampant black criminality, often seen by contemporary observers as the result of the failure of black women to realise respectable households. Even attempts on the part of the state to create respectable citizenries floundered, partly because these initiatives were incompatible with the policies of racial segregation. The state and the dominant bourgeoisie put their faith in the black elite as the standard-bearers of respectability, but the reality was that the respectability of the 'superior' class was frequently indistinguishable from those below, a consequence of the fact that the boundary between these classes was highly porous.
\end{abstract}

\section{Introduction}

This paper asks whether Cape Town's poor of the interwar years had values and a way of life that might be described as 'respectable'. In most histories of colonial societies, respectability is seen as the preserve of elites, both black and white, with the former largely imitative of the latter. Historians of Cape Town have argued that respectability was integral to the ruling ideology of the city's dominant white and English-speaking bourgeoisie. Indeed, the ideology, which had its roots in Britain, could be seen to have served as a historical bridge

\footnotetext{
${ }^{1}$ An earlier version of this paper was presented at Leiden University to celebrate the brilliant career of Professor Robert Ross. I am grateful to participants of that workshop, as well as to members of the Wits History Workshop and the Department of History at the University of South Africa for their insightful comments. I am especially indebted to Ruth Watson, Nicholas Southey and Angus Lockyer for their critical reading of respective drafts.
} 
This is the accepted version of an article that will be published by Cambridge University Press in The Journal of African History: https://www.cambridge.org/core/journals/journal-of-african-history/allissues

Accepted version downloaded from SOAS Research Online: http://eprints.soas.ac.uk/25963/

between nineteenth- and twentieth-century Cape Town. ${ }^{2}$ And yet, unlike inter- and post-war Johannesburg, where David Goodhew has shown that members of the African working class were deeply attached to the central tenets of respectability, the specific content and form of respectability in twentieth-century Cape has not been the subject of detailed historical investigation. ${ }^{3}$ This is especially true for respectability as it operated at its lowest level, within black households. Instead, much of the burden has fallen to anthropologists who have identified a version of respectability - what they call ordentlikheid, or decency - among the poor of the contemporary Western Cape. ${ }^{4}$ This paper aims to correct this historical lacuna, but also seeks to elaborate on Goodhew's concerns by interrogating the relationship between the respectability of the poor and that of the dominant white bourgeoisie. This paper also asks whether the poor of interwar Cape Town had a respectability of their own, that is, one that was not defined by the city's ruling class. The focus here is largely with the material manifestations of respectability, seen here as a quest for earning the respect of one's peers through certain forms of behaviour. Religious values as they pertained to both Islam and Christianity were clearly vital in this regard, but are beyond the scope of the current investigation.

The question of the relationship between poverty and respectability is worth asking, for poverty is frequently seen as an inhibitor of respectability. It was a question posed by contemporaries. 'When ... it is a choice between $6 \mathrm{~d}$. for soap and $6 \mathrm{~d}$. for a loaf, the loaf wins every time,' one welfare officer noted in $1935 .{ }^{5}$ Poverty stood in the way of all things respectable: cleanliness, godliness, industry, self-discipline in the form of temperance, sobriety, sexual restraint, education, and a seriousness of mind. Not least, respectability demanded attachment to a gendered notion of an ideal nuclear household. In the context of colonial Africa, where the adoption of European lifestyles was integral to Africans' pursuit of respectability, the attainment of its most familiar forms required a certain modicum of wealth. For a respectable life involved, probably first and foremost, investment in education, followed by brick or corrugated iron housing, furniture, books (as markers of education, to be

\footnotetext{
${ }^{2} \mathrm{~N}$. Worden et al, Cape Town, the making of a city (Cape Town, 1998); V. Bickford-Smith et al, Cape Town in the twentieth century (Cape Town, 1999).

${ }^{3}$ D. Goodhew, 'Working-class respectability: the example of the western areas of Johannesburg, 1930-55', Journal of African History (hereafter, JAH), 41, 2, 2000, 214-66; and Respectability and resistance: a history of Sophiatown (Westport, 2004).

${ }^{4}$ F. Ross, Raw life, new hope: decency, housing and everyday life in a post-apartheid community (Cape Town, 2010); S. Jensen, Gangs, politics and dignity in Cape Town (Chicago, 2008).

5 'Plight of the city's poor', Cape Argus, 13 July 1935.
} 
This is the accepted version of an article that will be published by Cambridge University Press in The Journal of African History: https://www.cambridge.org/core/journals/journal-of-african-history/allissues

Accepted version downloaded from SOAS Research Online: http://eprints.soas.ac.uk/25963/

sure, but also as material and status objects in and of themselves), fashionable clothing, and, with some luck, motor cars. In the British colonial world it necessarily required literacy in English. ${ }^{6}$ More recently, scholars have pointed to the importance of physical appearance in the pursuit of 'racial respectability'. In South Africa of the 1930s, beauty competitions involving African women became a terrain of broader gender struggles within African society and pointed to the malleability of notions of respectability in the hands of African men and women. ${ }^{7}$

The routes to elite respectability were typically to be found in peasant agriculture, as in the example of the Mfengu of the mid-nineteenth-century Eastern Cape, or in trading, as with the Yoruba elite of late-nineteenth and early twentieth-century Nigeria. ${ }^{8}$ In colonial Kenya, the opportunities presented by work on the railways encouraged new forms of respectability and offered a "new high road to urban civilisation. ${ }^{9}$ The proceeds of such endeavours could be invested in education, so that the heirs of the pioneers of African respectability typically occupied clerical posts in the colonial administration, or qualified as ordained clergy, schoolteachers, and, more rarely, as lawyers and medical doctors. Even though individuals in these occupations were to discover to their chagrin that education did not necessarily deliver affluence and, as in the South African case, increasingly found themselves squeezed out of the ranks of the amaRespectables and into those of workers and peasants, they were not the very poor, for whom respectability appeared to be beyond reach. ${ }^{10}$ In the mid-nineteenth century Cape, as Robert Ross has pointed out, the price of respectability was set precisely by the Colony's new constitution of 1853: 'Men whose property was worth $£ 25$ were within the limits, as were their families. ${ }^{11}$ While the specific financial requirement for the franchise was low enough for the Colony's liberal constitution to have real meaning for its black population, the price of respectability by this definition was simply too high for the Colony's

\footnotetext{
${ }^{6}$ J. Iliffe, Honour in African history (Cambridge, 2005), pp. 246-48.

${ }^{7}$ L.M. Thomas, 'The modern girl and racial respectability in 1930s South Africa', JAH 47, 3 , 2006, 461-90; see also E. Callaci, 'Dancehall politics: mobility, sexuality, and spectacles of racial respectability in late colonial Tanganyika, 1930s-1961', JAH, 52, 3, 2011, 365-84. ${ }^{8}$ Iliffe, Honour in African history

${ }^{9}$ J. Lonsdale, 'Town life in colonial Kenya', in A. Burton (ed.), The urban experience in Eastern Africa (Nairobi, 2002), p. 218.

${ }^{10}$ See, for example, H. Bradford, 'Mass movements and the petty bourgeoisie: the social origins of the ICU leadership, 1924-1929', JAH, 25, 3, 1984, 295-310; and A taste of freedom: the ICU in rural South Africa, 1924-30 (New Haven, 1987), pp. 65-74.

${ }^{11}$ R. Ross, Status and respectability in the Cape Colony 1750-1870: a tragedy of manners (Cambridge, 1999), p. 173.
} 
This is the accepted version of an article that will be published by Cambridge University Press in The Journal of African History: https://www.cambridge.org/core/journals/journal-of-african-history/allissues

Accepted version downloaded from SOAS Research Online: http://eprints.soas.ac.uk/25963/

poor, the majority of whom remained tied to an agricultural economy in circumstances of poverty and dependency. ${ }^{12}$

The phenomenon that most undermined these idealised notions of twentieth-century respectability was what colonial powers everywhere described as 'juvenile delinquency', and crime and criminality more generally. For at the beginning of the twentieth century, as Vivian Bickford-Smith and others have argued, the dominant values of Cape Town's white elite were challenged by the city's youth gangs. ${ }^{13}$ This was a specifically urban and male threat: in the case of South Africa, it came from tsotsis and amalaita in Johannesburg and Durban, and skollies in Cape Town. ${ }^{14}$ Liberal scholars and colonial authorities readily recognised that there existed a direct connection between 'juvenile delinquency' and poverty; mostly, however, they were concerned by the threat of youth criminality to the bourgeois order, and hence to respectability, a view which they shared with black elites. Cape Town's dominant classes failed to ask whether 'skollydom', the very antithesis of respectability in their eyes, could be constitutive of respectability itself.

\section{The nature of poverty}

Cape Town's poor of the interwar years were very poor. Grace Davie has recently argued that the historical nature of poverty in South Africa has be understood at two levels, firstly, 'as a real and violent condition that destroys people's lives, limits their contribution to society, and harms their relationships with each other,' and, secondly, 'as a fluid and layered conceptual space. ${ }^{15}$ It is with the first of these that this paper is concerned. Although the white population was not unaffected, the combined legacies of colonial dispossession, slavery, and state-driven racial segregation meant that the experience of poverty was almost wholly confined to the city's black population, coloured and African. ${ }^{16}$ This was a poverty driven by

\footnotetext{
${ }^{12}$ S. Trapido, 'The friends of the natives: the origins of the Cape franchise qualifications of 1853', JAH, 5, 1, 1964, 37-54.

${ }^{13}$ Bickford-Smith et al, Cape Town in the twentieth century, p. 44.

${ }^{14}$ P. La Hausse, "The cows of Nongoloza": youth crime and Amalaita gangs in Durban, 1900-1936', Journal of Southern African Studies (hereafter, JSAS), 16, 1, 1990, 79-111; A. Mager, 'Youth organisations and the construction of masculine identities in the Ciskei and Transkei, 1945-60', JSAS, 24, 4, 1998, 653-67; C. Glaser, Bo Tsotsi: the youth gangs of Soweto, 1935-1976 (Oxford, 2000).

${ }^{15}$ G. Davie, Poverty knowledge in South Africa: a social history of human sciences, 1855 2005 (Cambridge, 2015), p. 3.

${ }^{16}$ Throughout this paper I use the term 'black' to collectively refer to all persons not white. The word 'coloured' first came into general use after the ending of slavery, and was almost
} 
This is the accepted version of an article that will be published by Cambridge University Press in The Journal of African History: https://www.cambridge.org/core/journals/journal-of-african-history/allissues

Accepted version downloaded from SOAS Research Online: http://eprints.soas.ac.uk/25963/

the competition for resources in the wake economic change, more rapid and deeper in South Africa than elsewhere on the continent. During the first half of the twentieth century the South African state by and large succeeded in eliminating multiracial poverty; from this time on, poverty was identified with blackness. ${ }^{17}$ The nature and extent of black poverty attracted the attention of a range of contemporary observers, including church leaders, liberal commentators and university academics. Furthermore, two major government commissions the Native Economic Commission (1932) and the Wilcocks Commission into coloured poverty (1937) - investigated questions of black standards of living. ${ }^{18}$

In Cape Town, as elsewhere, poverty manifested itself in a number of ways, but poor housing, ill health and shortened lifespans were among the most obvious manifestations. From the very beginning of the twentieth century, when reliable figures on health and mortality became more readily available, it was clear that the black population suffered ill health and premature mortality vastly in excess of their white counterparts. In 1903, for example, the main 'preventable diseases' - tuberculosis, bronchitis, and pneumonia - were responsible for 3.35 deaths per thousand among the country's white population; for the black population, by contrast, the figure was 19.02 per thousand, nearly six times as high. At the same time, tuberculosis alone killed 8.09 per thousand people of the Colony's black population. So widespread was the incidence of tuberculosis that a government commission was appointed to investigate the origins and repercussions of the disease. ${ }^{19}$

always used to describe the former slaves, indigenous Khoisan and the descendants of these groups who had coalesced into a single underclass during the second half of the nineteenth century. The term was only one of a number of words used to describe such peoples, but one that became increasingly commonplace, and was, importantly, taken up by the more elite members of this class as a form of self-identification. (See V. Bickford-Smith, 'Black ethnicities, communities, and political expression in late Victorian Cape Town', $J A H, 36,3$, 1995, 443-65, esp. p. 452; M. Adhikari, “" The product of civilisation in its most repellent manifestation": ambiguities in the racial perceptions of the APO (African Political Organisation), 1909-1923', JAH, 38, 2, 1997, 283-300, p. 285.) The term 'African' is used to refer to first-language speakers of Bantu languages. As used here, these descriptors do not, of course, denote reified racial categories, but it is important to recognise that the forms of statesponsored racial discrimination ensured that the lived experiences of Africans and coloureds could differ significantly.

${ }^{17}$ J. Iliffe, The African poor: a history (Cambridge, 1987), p. 114.

${ }^{18}$ Union of South Africa (hereafter, UG) 22 - '32, Report of Native Economic Commission, 1930-32; UG.54-'37, Report of Commission of Inquiry regarding Cape Coloured Population of the Union of South Africa (Wilcocks Commission). In addition to the published report of the Wilcocks Commission, I have also drawn on evidence submitted to that commission, copies of which are held in the African Studies Library, University of Cambridge.

${ }^{19}$ G35*-1904 (Cape Parliamentary Papers), Report of the Medical Officer of Health for the Colony, John Gregory, together with the health report of district surgeons and local 
This is the accepted version of an article that will be published by Cambridge University Press in The Journal of African History: https://www.cambridge.org/core/journals/journal-of-african-history/allissues

Accepted version downloaded from SOAS Research Online: http://eprints.soas.ac.uk/25963/

Throughout the interwar years, Cape Town's black population continued to suffer severe ill health. During 'Black October', the first few weeks of the great influenza epidemic of 1918, at least 7,000 lives were lost in the Cape Peninsula, with the coloured population paying the greatest price. ${ }^{20}$ In subsequent years, tuberculosis remained the biggest scourge and the single largest cause of death across all recorded categories, including 'violence'. ${ }^{21}$ Through to the Second World War, tuberculosis continued to kill Cape Town's black population in large and disproportionate numbers. ${ }^{22}$

Poor diets aside, by far the greatest source of ill health and inflated mortality was to be found in a severe shortage of housing, as a result of which the city's poor were left to endure conditions that were both overcrowded and highly infectious. During the first half of the twentieth century, Cape Town experienced a fully-fledged housing crisis. ${ }^{23}$ The crisis had its origins in the nineteenth century, but a severe housing shortage became especially apparent during the last decade of the century when new employment opportunities in the docks and related industries attracted large numbers of migrants from the countryside. It was in the heart of the city, in the area that became known as District Six, where the worst conditions were most visible. In the aftermath of the South African War (1899-1902) much of the vacant land on the slopes of Devil's Peak and many of the houses once owned by substantial slaveowning families were acquired by a new landlord class who were able to earn substantial profits by squeezing ever more people into their properties. ${ }^{24}$

Houses in the city centre thus became rapidly and severely overcrowded. ${ }^{25}$ Unsurprisingly, these conditions did not make for healthy environments. It was not

authorities, for the half-year ended 30 June 1904; UG.34-'14, Report of the Tuberculosis Commission.

${ }^{20}$ UG.40-'24, Report on the third census of the Population of the Union of South Africa, enumerated 3 May 1921, Part X; 'In the underworld of Cape Town', Cape Times, 13 Feb. 1922; “"Black October” ten years ago', Cape Argus, 24 Oct. 1928; H. Phillips, 'Black October': the impact of the Spanish influenza epidemic of 1918 on South Africa (Pretoria, 1990).

${ }^{21}$ National Archives of South Africa, Cape Town (hereafter, CA) 3/CT 4/1/9/1/9, Report of the Government Departmental Committee to explore ways and means of improving health and social conditions of natives in urban areas other than increasing wages (Smit Committee), 1941.

${ }^{22}$ CA 3/CT 4/1/9/1/9, Report of the Smit Committee, 1941.

${ }^{23}$ W. Dooling, "“Cape Town knows, but she forgets": segregation and the making of a housing crisis during the first half of the twentieth century', JSAS, forthcoming.

24 'Raiding the dope sellers of Cape Town', Cape Argus, 16 Oct. 1926; CA 3/CT 4/1/5/1258, 'City native at "home", 29 April 1931.

25 'Slum menace in Cape Town', Cape Argus, 9 Feb. 1927; 'Clean up Cape Town's plague spots', Cape Times, 2 Sep. 1933; University of the Witwatersrand (Wits) Historical Papers, 
This is the accepted version of an article that will be published by Cambridge University Press in The Journal of African History: https://www.cambridge.org/core/journals/journal-of-african-history/allissues

Accepted version downloaded from SOAS Research Online: http://eprints.soas.ac.uk/25963/

uncommon for 50 or more people to share a single lavatory. 'Everything is communal,' wrote the Cape Argus. 'Lavatories, taps, tubs, yards, kitchens, rooms, even beds, and this community existence is carried on in such an atmosphere which is often nauseating and never fresh. ${ }^{26}$ A 1933 housing survey of a number of wards in the city centre revealed that no dedicated bathroom was provided in 96 per cent of cases, while tenants had to make do without an inside tap in 88 per cent of instances; in 85 per cent of cases toilet facilities were absent for the exclusive use of individual lettings. ${ }^{27}$ Health professionals and liberal commentators were united and unequivocal about the direct correlation that existed between the housing shortage, chronic ill health, and disproportionately high mortality rates among the city's black population. ${ }^{28}$

Conditions such as these were not merely confined to the city centre. Housing conditions were as lacking in N'dabeni, the 'location' established by the colonial government for African occupation at the time of the bubonic plague in $1901 .{ }^{29}$ By the end of the $1920 \mathrm{~s}$, N'dabeni was home to some 4,500 people. Dwellings consisted of dormitories, laid out in rows of corrugated iron huts. ${ }^{30}$ African leaders resented conditions here: "“There is scarcely a house in the whole location," said one man, "that has proper ventilation. In one room, in many cases, a man and family have to live, cook, eat and sleep. The overcrowding is dreadful." ${ }^{31}$ In 1929 the Chief Medical Officer deemed living quarters for 90 per cent of N'dabeni's inhabitants to be 'unfit for human habitation., ${ }^{, 32}$

Out on the Cape Flats, where African and coloured families established themselves in settlements of pondokkies - ramshackle dwellings fashioned from all manner of materials including sacks, branches, paraffin tins, or corrugated iron - conditions were at least as bad. Known as the 'plague spot on the [Cape] Peninsula', the neighbourhood of Windermere was thought to be one of the worst. Here, coloured and African families lived in close proximity, the latter seeking to escape the restrictions of the Native (Urban Areas) Act of 1923 and resisting removal to the new 'model' township of Langa that was opened in 1927. In 1930

Digitised Collections, Native Economic Commission, Cape Town, vol. 4, Evidence of Sir Clarkson Tredgold, 23 April 1931.

26 'Clean up Cape Town's plague spots', Cape Argus, 2 Sep. 1933.

${ }^{27}$ CA 3/CT 4/1/5/576, Evidence of Dr. T. Shadick Higgins, 16 April 1934.

${ }^{28}$ CA 3/CT 4/1/5/576, Housing Survey, Interim report, Wards, 2 -6, 1934.

${ }^{29}$ Wits Historical Papers, Native Economic Commission, Cape Town, vol. 4, 'Historical, Ndabeni Location, Maitland,' written evidence presented, 1931.

30 'A walk round Ndabeni', Cape Argus, 22 Sep. 1930.

31 'The creation of Langa', Cape Argus, 5 Jan. 1924.

${ }^{32}$ CA 3/CT 4/1/5/1248, Ndabeni location: report of the Medical Officer of Health: general health conditions, 21 Dec. 1934. 
This is the accepted version of an article that will be published by Cambridge University Press in The Journal of African History: https://www.cambridge.org/core/journals/journal-of-african-history/allissues

Accepted version downloaded from SOAS Research Online: http://eprints.soas.ac.uk/25963/

'hundreds of tin shanties' were seen in the bush at Windermere. ${ }^{33}$ Conditions were very far from sanitary, especially as much of the area was under water during Cape Town's wet winter months. The area had no regular service of refuse collection and human waste was simply buried in the soil between dwellings. ${ }^{34}$

Poor housing, ill health and inflated mortality rates were manifestations of black poverty. At the heart of black poverty, however, was the fact of low wages. Wage gains made by black workers during the First World War were quickly stripped away in subsequent years. However, the depths of misery experienced during the 1920 s were more directly a consequence of the Pact government's 'civilised labour' regime, a set of policies introduced almost immediately after this alliance of the Labour and National Parties came to power in 1924. Underpinning the civilised labour policy were the Wages Act (1925), which set minimum 'civilised' wages in trades and industries not already governed by legislation, and the Mines and Works (Amendment) Act (1926), or the Colour Bar Act, as the latter was more popularly known. The Pact government defined and defended these policies in explicitly racial terms: 'civilised labour' was 'the labour rendered by persons whose standard of living conforms to the standard general regarded as tolerable from the European standpoint.' By contrast, 'uncivilised labour' was that 'rendered by persons whose aim is restricted to the requirements of the necessities of life as understood among barbarous and undeveloped peoples. $^{35}$

Although the Pact sought to distinguish between coloured and African workers, by promoting the 'civilised labour' policy as a 'New Deal' to the former, the results were disastrous for black workers all round. ${ }^{36}$ The Economic and Wage Commission of 1926 found that real wages were lower on the whole than they had been in $1910 .{ }^{37}$ At the docks, one of the most important places of employment in the city, coloured men were clearly privileged over African workers who were dismissed wholesale. ${ }^{38}$ Coloured workers, on the other hand, found themselves squeezed between suppressed wages and unemployment. ${ }^{39}$

\footnotetext{
33 'Big police raid at Windermere', Cape Times, 15 Sep. 1930.

${ }^{34}$ CA 3/CT 4/1/9/1/7, T.S. Higgins - General Purposes Committee, City of Cape Town, 9 Sep. 1941.

${ }^{35}$ Cited by G. Lewis, Between the wire and the wall: a history of South African "coloured" politics (Cape Town, 1987), pp. 132-33.

36 'Native unrest at the docks', Cape Argus, 11 Feb. 1926; 'Natives ousting coloured workers', Cape Argus, 27 Oct. 1925.

37 'Economic and Wage Commission', Cape Argus, 21 May 1926.

38 'Native unrest at the docks', Cape Argus, 11 Feb. 1926; 'Coloured labour at the docks', Cape Argus, 12 Feb. 1926; 'Natives ousting coloured workers', Cape Argus, 27 Oct. 1925.

39 'Urban natives', Cape Argus, 17 Jan. 1936.
} 
This is the accepted version of an article that will be published by Cambridge University Press in The Journal of African History: https://www.cambridge.org/core/journals/journal-of-african-history/allissues

Accepted version downloaded from SOAS Research Online: http://eprints.soas.ac.uk/25963/

Conditions deteriorated sharply during the Depression years. Coloured railway workers had their wages cut by between 6 and 25 per cent, while maximum rates of pay for certain grades of work were reduced the following year. ${ }^{40}$ In mid-1929 dock workers' wages amounted to only 50 per cent of their earnings of two years earlier. ${ }^{41}$ While a few African stevedores or those who worked in the construction industry could earn up to $6 \mathrm{~s}$. - 8s. per day, the vast majority of labourers earned no more than 3 s. per day. ${ }^{42}$ By 1937 , coloured workers were said to earn only half of what had been the case ten years previously. ${ }^{43}$

Statements about the inadequacy of black wages were borne out by detailed investigations into household 'budgets' and the 'cost of living.' In 1932, a government commission found that the standard of living of the Union's urban population had declined by between 30 and 50 per cent since the onset of the Depression. ${ }^{44}$ Declining wages combined fatally with rising prices: in mid-1930 the cost of food in Cape Town was measured as being 23 per cent higher than that of 1914, while the general cost of living rose by 38 per cent in the same period. ${ }^{45}$ It was clear that the wages fell short of basic maintenance requirements. At the beginning of the 1930s, when average wages of African men in Langa and N'dabeni stood at around $£ 4$ per month, a 'committee of natives' calculated the monthly cost of living of a household of four (man, woman, and two children) as being $£ 6.9 .0$; at N'dabeni, a household consisting of a man, woman, and four children was said to require $£ 2.5 .11 \frac{3 / 4}{4}$ pence per week to meet their living requirements, well short of the average wages of African men. ${ }^{46}$ Five years later, households in Langa faced similar circumstances. Then, the 'cost of living' for a 'native and three dependants' was estimated at $£ 6$ per month as against a male labourer's monthly wage of $£ 4$, leaving the household 'unable to pay rent, train fares and other charges. ${ }^{47}$

'Cost of living' investigations focused almost exclusively on male earnings. Yet, it was clear that in Cape Town, as in other South African cities, the labouring efforts of women and

\footnotetext{
40 'Plea of coloured railwaymen', Cape Argus, 16 Feb. 1935.

${ }^{41}$ 'When the last penny has been spent', Cape Argus, 29 July 1929.

${ }^{42}$ Wits Historical Papers, Native Economic Commission, Cape Town, vol. 4, Statement by Rev. A. Mtimkulu, 24 April 1931.

${ }^{43}$ Wits Historical Papers, Native Economic Commission, Cape Town, vol. 4, Evidence of N.R. Veldsman, 25 April 1931; 'Coloured people "robbed" of their rights', Cape Argus, 25 June 1937; Lewis, Between the wire and the wall, p. 152.

44 'House rents still too high', Cape Times, 4 Feb. 1933.

45 'Cape Town's cost of living', Cape Argus, 1 Aug. 1930.

${ }^{46}$ Wits Historical Papers, Native Economic Commission, Cape Town, vol. 4, Evidence of Sir Clarkson Tredgold, 23 April 1931.

47 'Langa can only succeed as a slum', Cape Argus, 15 June 1935.
} 
This is the accepted version of an article that will be published by Cambridge University Press in The Journal of African History: https://www.cambridge.org/core/journals/journal-of-african-history/allissues

Accepted version downloaded from SOAS Research Online: http://eprints.soas.ac.uk/25963/

children were vital to the economic survival of black families. In many cases, these were the only sources of income. ${ }^{48}$ While African women found employment opportunities in the brewing of beer, the sale of foodstuffs, and the taking in of laundry, coloured women were overwhelmingly tied to domestic labour, greater employment opportunities in factories notwithstanding. ${ }^{49}$ In 1921 some 50,000 women, or about 32 per cent of the total coloured female workforce in the Cape, were employed in poorly paid domestic service. Only 6,000 women worked in industry. ${ }^{50}$ Children, too, were often forced to contribute to household earnings. ${ }^{51}$ Limited educational opportunities propelled black children into paid work at a young age. Most commonly, young coloured boys sold newspapers - these 'Argie boys', so called after the newspaper for which they worked, the Cape Argus, could earn about 6s. per week, but boys and girls also earned money by hawking fruit, vegetable and wood, or by serving as lookouts for illicit liquor sellers. ${ }^{52}$

Despite these labouring efforts, low wages ensured that Cape Town's black population suffered overwhelming poverty, levels of which deepened in the aftermath of the First World War, and further still during the years of the Great Depression. Indeed, the term 'wage', argued Bishop Sydney Lavis, was a misnomer since the remuneration received by unskilled labourers was no more than 'payment' as it bore 'no relation to a decent living. ${ }^{53}$ It was not merely that low wages ensured the poverty of the city's black population; it was that poverty defined their entire existence.

\section{In search of respectability}

For such poor, chronically sick, malnourished, and poorly housed persons, respectability was hard to come by. Cape Town's more liberal commentators assumed that the general conditions under which the city's black population lived - especially the related circumstances of poverty and poor housing - stood in the way of respectability.

\footnotetext{
${ }^{48}$ CA 3/CT 4/1/9/1/8, Report of the Smit Committee, 1941.

${ }^{49}$ CA 3/CT 4/1/9/1/8, Native Affairs Commission, Use and supply of Kaffir Beer in urban areas and removal of redundant natives from urban areas (1941/42), 10 Oct. 1941; 'White women visit Ndabeni', Cape Argus, 17 Aug. 1928; UG.22-'32, Report of the Native Economic Commission; 'Domestic servants must be better treated', Cape Argus, 10 Feb. 1938; Iliffe, Honour, p. 279.

${ }^{50}$ UG. 54-'37, Wilcocks Commission Report, pp. 69-70.

${ }^{51}$ CA 1/CT 420, 20/8/12, Probation Officer's Monthly Report, 29 March 1935.

52 'Memorandum by J. de Kock, Probation Officer, Cape Town, Evidence presented to the Wilcocks Commission, 29 March 1935; Pinnock, 'Argie Boys', p. 147.

53 'The hell in which the Coloured man lives', by Bishop S.W. Lavis, The Sun, 8 July 1938.
} 
This is the accepted version of an article that will be published by Cambridge University Press in The Journal of African History: https://www.cambridge.org/core/journals/journal-of-african-history/allissues

Accepted version downloaded from SOAS Research Online: http://eprints.soas.ac.uk/25963/

Overcrowding, noted Cape Town's Medical Officer of health, produced not only problems of poor health, but also ones that could be seen 'from a social point of view. ${ }^{54}$ In an examination of the city's housing crisis, the Journal of the Medical Association of South Africa concluded that, quite apart from issues of health, the resultant overcrowding was injurious to the " moral character of the people.",55 Charitable organisations reached the same conclusions, namely, that the poor lived under conditions that were not only 'degrading in the extreme' and a 'menace to public health', but that were also a threat to 'morality ... and the decencies of life. ${ }^{56}$ In circumstances where entire families were crowded into single rooms, there could be 'no family life,' argued Cape Town's Probation Officer. ${ }^{57}$ In short, the consequences of poor housing seeped into the very fabric of everyday life. Most importantly, poverty and the housing crisis challenged the most important tenets of respectability: cleanliness, sexual propriety and a culture of domesticity structured around an idealised patriarchal household.

Cleanliness came at a price. In the pondokkies on the Cape Flats, housing conditions and the absence of municipal services made it 'quite impossible' for inhabitants to remain clean. Even in central Cape Town, the poor lacked basic sanitary facilities. Poverty in District Six, so believed those who ran the city's charitable institutions, often forced households to give up on attempts at cleanliness 'bit by bit. ${ }^{58}$ Although there were municipal washhouses situated at Signal Hill in central Cape Town, the cost of use - sixpence per adult for a hot bath - put them beyond the reach of the poor. These 'spotless bathrooms' with 'shining tubs' were very infrequently used as facilities for personal bathing. During December 1928, for example, only 93 adult hot baths were sold, while children availed themselves of 42 hot and nine cold baths. Instead, the washhouses, where cold-water wash tubs and electric irons could be rented for four pence a day and a penny an hour respectively, served primarily as a place for the city's coloured washer women to do the laundry of white households. ${ }^{59}$

Sexual propriety, too, was an obvious victim of poverty. One of the results of the housing shortage was that young people delayed the age of marriage, or began 'married life

\footnotetext{
54 'The slum menace in Cape Town', Cape Argus, 13 Aug. 1927.

55 'Overcrowding in Cape Town', Cape Argus, 10 June 1929.

56 'Living in degrading conditions', Cape Argus, 25 Aug. 1928.

57 'Memorandum by Joseph de Kock', Evidence presented to Wilcocks Commission, 29 March 1935.

58 'Marion Institute', Cape Argus, 15 Feb. 1922.

59 'Where Cape Town's clothes are washed', Cape Argus, 15 Jan. 1929.
} 
This is the accepted version of an article that will be published by Cambridge University Press in The Journal of African History: https://www.cambridge.org/core/journals/journal-of-african-history/allissues

Accepted version downloaded from SOAS Research Online: http://eprints.soas.ac.uk/25963/

in a corner of their parents' room, or in some other overcrowded hovel. ${ }^{60}$ The most immediate consequence of delayed marriage was high rates of 'illegitimacy', a phenomenon that the Wilcocks Commission blamed squarely on the 'indecent, evil housing conditions' and the 'impossibility of separation at night of adolescents, of children from adults. ${ }^{61}$ These conditions, the Commission concluded, led to 'unconventional sex relations. ${ }^{62}$ In Cape Town, 23 per cent of coloured children were said to be born out of wedlock in the five years leading up to 1935, a rate that was four times higher than that of the white population, but somewhat lower than the figure of 50 per cent for African births in towns in the Union as a whole, where the social premium placed on women's fertility outweighed concerns over 'illegitimacy'. ${ }^{63}$

In the eyes of Cape Town's bourgeois commentators, one of the most dire consequences of low male wages and poverty was that women were propelled into wage labour and thus away from domestic responsibilities. These concerns have to be understood within the context of developments in Britain. During the first half the twentieth century, the British state actively disseminated an ideology of domesticity throughout British workingclass life. Closely related to this was an 'ideology of childhood'. Thus British working class women were given lessons in cleanliness, hygiene, thrift, and temperance, while girls were 'educated' in the arts of domestic science and 'home-making.' At the heart of this ideological package was the idea that a woman's most important duty was that of a mother and that her place was in the home. Here she bore primarily responsibility for raising children in happy, clean, and healthy environments. ${ }^{64}$

Throughout British colonial Africa, African men and women were at the receiving end of these ideological impulses. Here, however, Christian missionaries were the primary carriers. Their efforts met with varying degrees of success, for African men resisted European attempts at transforming domestic relations and were, John Iliffe has argued, by and large successful in the 'reshaping of Christian respectability to male advantage. ${ }^{65}$ In Johannesburg, as elsewhere, white missionaries actively sought to promote ideas of domesticity and Christian womanhood among the urban African population. Naturally, women were the

\footnotetext{
60 'Housing shortage in Cape Town', Cape Argus, 25 Aug. 1928.

61 'The Hell in which the Coloured man lives', by Sydney Lavis, The Sun, 8 July 1938.

${ }^{62}$ UG. 54-'37, Wilcocks Commission Report, p. 20.

${ }^{63}$ Statement of Dr. T. Shadick Higgins, Evidence presented to Wilcocks Commission, 1 May 1935; Iliffe, Honour, p. 264.

${ }^{64}$ D. Gittins, Fair sex: family size and structure, 1900-39 (London, 1982), pp. 42-49, 60-61, 183.

${ }^{65}$ Iliffe, Honour, p. 273.
} 
This is the accepted version of an article that will be published by Cambridge University Press in The Journal of African History: https://www.cambridge.org/core/journals/journal-of-african-history/allissues

Accepted version downloaded from SOAS Research Online: http://eprints.soas.ac.uk/25963/

special targets of their efforts; as Deborah Gaitskell has shown, missionary activity in Johannesburg was imbued with a domestic vision for African families, one in which African women were mothers and 'housewives', the latter concept alien to rural African society of the nineteenth century. On this front, the missionaries had some success. African women imbibed the language of domesticity and can be seen to have fought for it, in no small measure due to the fact that the message 'resonated both with the pre-Christian family role of African women and their post-industrial daily experience.' To such women the ideology of domesticity brought prestige, respect and the mechanisms with which to defend families under threat of disintegration. ${ }^{66}$

The missionary vision, however, pressed up against the economic realities of the Great Depression. In Johannesburg, as in Cape Town, low male earnings compelled women to enter the wage labour market, diminishing their roles as full-time mothers and housewives. African women worked in a range of occupations, but certain ones, such as prostitution or the brewing of beer, were distinctly lacking in Christian respectability. The supposed injurious impact upon African homes of women entering the labour market led to calls on the part of missionaries and others for increased African wages. Most significantly, there were calls for action on 'juvenile delinquency', the phenomenon seen as the most obvious consequence of women's diminished role in childrearing and which, not unimportantly, represented a direct threat to white society. ${ }^{67}$

Similar ideologies were at work in Cape Town. Churches and charitable institutions were at the forefront of promoting a vision of domestic respectability predicated upon the view that women were to be housewives and the primary carers of children. Thus the Marion Institute, founded in 1917 as a 'club for young coloured girls', set itself the task of 'turning little waifs and strays into respectable citizens. ${ }^{68}$ Most of their work was in District Six, where they offered Bible classes, lessons in sewing and knitting, and cheap meals. The 'Mother's Class' provided facilities where young married women could meet to acquire lessons in domestic arts. ${ }^{69}$ Attached to the Institute were divisions of the Wayfarers Association, the organisation founded by white liberals in Johannesburg and which adapted the model of the Girl Guides to urban African "“needs" so as to impart lessons in home-

\footnotetext{
${ }^{66}$ D. Gaitskell, 'Housewives, maids or mothers: some contradictions of domesticity for Christian woman in Johannesburg, 1903-39', JAH, 24, 2, 1983, pp. 241-56, esp. pp. 241-43, 245, 250, 252, 255.

${ }^{67}$ Wits Historical Papers, AD 843 B56.4, 'Bantu juvenile delinquency conference', 1939.

68 'The Marion Institute', Cape Argus, 18 May 1922.

69 'Work of the Marion Institute', Cape Argus, 12 March 1930.
} 
This is the accepted version of an article that will be published by Cambridge University Press in The Journal of African History: https://www.cambridge.org/core/journals/journal-of-african-history/allissues

Accepted version downloaded from SOAS Research Online: http://eprints.soas.ac.uk/25963/

making, domesticity, and respectability. ${ }^{70}$ The Wayfarers were especially concerned with issues of 'morality' in the face of 'temptations' offered by the city, and those behind the Association saw the opportunity of 'getting at the girls one by one. ${ }^{, 71}$

As in Britain, these ideas were taken up by elements within the state. The natural position of women, according to the Wilcocks Commission, was that of 'home-maker.' Thus much of the Commission's investigation was explicitly concerned with the question of the suitability of coloured women to this role. Across the Union, informants were specifically asked to comment on the topic of 'The Coloured woman as home-maker.' Cape Town's Probation Officer distinguished between 'better class' women and those of the 'lower classes.' The former, he believed, were 'good home-makers,' despite having to make do with small incomes. The same could not be said for women from the 'lower classes,' those who lived 'in hovels in their thousands on the [Cape] Flats. ${ }^{72}$ In the eyes of white opinion, this category of woman had failed. All in all, even though coloured women had put up a 'pathetically brave fight' to meet these specifically gendered demands of 'home-making', it was one that they had lost:

The proper performance of the function of the mother as homemaker presupposes that the husband earns enough to meet, at least the essential household requirements, but the weekly income of the family is very often too small for even an approximate satisfaction of elementary needs. The task of the homemaker is made even more difficult when the earnings of the husband are so inadequate that she has to eke out the family income by washing or some other wage-earning employment. When working away from home she has, as a rule, no opportunity of properly preparing food for the family; indeed she has neither the time nor the energy for wage-earning as well as home-making and the training of her children, even if she is competent to fulfil the latter functions. ${ }^{73}$

\section{Respectability from above}

It was especially in the planning and establishment of the new African township of Langa, officially opened in 1927 and built in accordance with the Native (Urban Areas) Act of 1923, that the local state sought to impose a vision of domestic respectability. In keeping with the 1923 Act, city authorities recognised that Langa was not to be 'merely a place for the

\footnotetext{
${ }^{70}$ A. Cobley, The rules of the game: struggles in black recreation and social welfare policy in South Africa, (Westport, 1997), pp. 82-83.

71 'Work of the Marion Institute', Cape Argus, 12 March 1930.

72 'Memorandum by Joseph de Kock', Evidence presented to the Wilcocks Commission, 29 March 1935.

${ }^{73}$ UG. 54-'37, Wilcocks Commission Report, p. 19.
} 
This is the accepted version of an article that will be published by Cambridge University Press in The Journal of African History: https://www.cambridge.org/core/journals/journal-of-african-history/allissues

Accepted version downloaded from SOAS Research Online: http://eprints.soas.ac.uk/25963/

temporary accommodation of native people, but a place of residence'; the township was to be home to 'a very large number of natives who have acquired civilised habits of life.' Thus provision was to be made 'for the strengthening of the home spirit and the development of a civic conscience.' The township had to provide for what had become 'a new urban race,' one in which 'family life' had become 'a reality.' In due course, authorities claimed, the township would 'afford opportunities for recreation, self-help, and self-improvement." ${ }^{74}$

But these stated principles ran up against others, namely, segregation, control and containment. In the first instance, the state was determined to control the 'influx' of Africans into urban areas, and especially the movement of African women into towns. Though the Native (Urban Areas) Act recognised that Africans had become permanent residents of urban areas, the Act's guiding principle was that Africans would be allowed to remain in towns only for as long as they served the needs of white industry and white households. ${ }^{75}$ Thus local officialdom saw the township as primarily a place for single African men, those 'drifting about' who were 'a potential menace to the [white] community. ${ }^{, 76}$ Intended ultimately to house 5,000 men, women, and children, Langa provided accommodation for 2,200 single African men at the time of its opening; married couples were initially permitted to remain in the older location of $\mathrm{N}^{\prime}$ dabeni. ${ }^{77}$ When the township was established, the city council recommended a 'barrack system' of accommodation along the lines of the mining compound at the City Deep Mine in Johannesburg. ${ }^{78}$ The barracks consisted of four blocks in the form of a double rectangle, with each block divided into rooms that could house as many as twenty-five men who slept on bunks arranged two-deep along the walls, 'very much like bunks in a ship, and similar in some respects to some of the best compounds on the Rand. 79

Secondly, it was clear from the start that the control and containment of this population was integral to the planning of the township. ${ }^{80}$ Langa was 'not a township,' complained the local chairman of the African National Congress (ANC), 'but a compound, for the natives

\footnotetext{
74 'A new township in the making', Cape Argus, 4 June 1927; 'The creation of Langa', Cape Argus, 5 Jan. 1924.

${ }^{75}$ T.R.H. Davenport, 'African Townsmen? South African Natives (Urban Areas) Legislation through the Years', African Affairs, 68, 1969, 95-109.

76 'The native township', Cape Argus, 21 Dec. 1923.

77 “'Smelling out” 2,000 natives', Cape Argus, 9 Sep. 1927; 'The luxuries of Langa', Cape Argus, 15 Sep. 1927; 'Stage set for next location move', Cape Argus, 10 July 1930; Native Economic Commission, vol. 4, Cape Town, Written Evidence, 1931.

78 'The development of Langa', Native Economic Commission, Vol. 4, Cape Town, Written Evidence, 1931.

79 'A new township in the making', Cape Argus, 4 June 1927.

80 'The new Langa location', Cape Argus, 5 Dec. 1925.
} 
This is the accepted version of an article that will be published by Cambridge University Press in The Journal of African History: https://www.cambridge.org/core/journals/journal-of-african-history/allissues

Accepted version downloaded from SOAS Research Online: http://eprints.soas.ac.uk/25963/

were herded together like swine. ${ }^{81}$ Overseeing the township was a Superintendent who was tasked with keeping the "natives under his charge healthy, cleanly, and orderly. ${ }^{, 82}$ In the event of 'any disturbance', police could 'close the gates and isolate the inhabitants. ${ }^{83}$ But authorities clearly believed that these attempts at control were entirely compatible with elements of respectability. Thus occupants were to be subjected to cleaning regimes that resembled industrial operations: once every three weeks the barracks were to undergo 'complete cleaning and disinfecting,' during which time the men's bunks were 'taken out and scrubbed, their entire room cleansed and re-whitewashed and disinfected, and all their clothes and gear taken to the sterilising station and treated.' Single men had access to 'a set of baths with a copious supply of water. ${ }^{, 84}$ Attached to one of the washing rooms was a large 'disinfecting room.' 85

In the end, the state's concerns with influx control and social containment outweighed the ideal of respectability, a nuclear household comprising husband, wife, and children. Influx control put paid to the demographic basis for this version of respectability. Although the construction of married quarters commenced in mid-1927, these were very limited, initially comprising only six two-roomed houses that were segregated from the quarters for single men. ${ }^{86}$ By September 1930 Langa had married accommodation for 300 people only. Access to these quarters was strictly controlled and could involve criminal prosecution. Ida Sikupela, for example, was initially fined $£ 5$ or twenty-one days imprisonment with hard labour for refusing to vacate a house in the married quarters when municipal authorities declared her to be a 'widow' following her husband's extended absence. ${ }^{87}$ Through to the Second World War the township remained overwhelmingly a place of single men: in 1931 Langa's population comprised 1,236 men, 339 women, and 363 children. The census of 1938 counted an African population in Langa of 3,855 persons, of whom 3,056 were men; only 799 were women. Although Langa's adult population increased in the following two-and-ahalf years, to 4,062 people in total, the number of women had in fact dropped to 713. As late

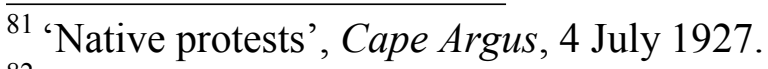

82 'The new Langa location', Cape Argus, 5 Dec. 1925.

83 'Removing natives from the city', Cape Argus, 19 Dec. 1923.

84 'The new Langa location', Cape Argus, 5 Dec. 1925.

85 'A new township in the making', Cape Argus, 4 June 1927.

${ }^{86}$ Native Economic Commission, Evidence of Dr. T. Shadick Higgins, vol. 4, Cape Town, 28 April 1931.

${ }^{87}$ CA CSC 1/3/1/15, Appeal in case of Ida Sikupela vs Rex, 4 Oct. 1930.
} 
This is the accepted version of an article that will be published by Cambridge University Press in The Journal of African History: https://www.cambridge.org/core/journals/journal-of-african-history/allissues

Accepted version downloaded from SOAS Research Online: http://eprints.soas.ac.uk/25963/

as 1941 , only 600 of the adult men lived in married accommodation. ${ }^{88}$ In 1957 , at which time apartheid-era officials decided that the 'future development of Langa shall be for single male natives only,' the township had 1,764 adult female residents as against 24,277 men. ${ }^{89}$

Unsurprisingly, the idea of Langa as a home for single men caused much discontent among those forced to move there. 'One reason why some people call Langa a compound,' Sol Plaatje of the ANC wrote, 'is that native males are separate from their womenfolk. Only compounds are associated in the native mind with the segregation of the sexes.' It was little wonder, then, that men quit the township. ${ }^{90}$ Moreover, those who managed to secure housing in Langa's married quarters had further cause for unhappiness. Firstly, at 7s. per week, the rental cost of such accommodation was very high, and 'definitely ... beyond a man's living,' James Ngeto told the Chairman of the City Council's Native Affairs Committee in 1930. ${ }^{91}$ Those unable to pay were liable to arrest and imprisonment, causing deep resentment. 'There was a man arrested by the Council here,' Sprig Mambobo recalled, 'simply because he could not afford to pay his full rent. That man was ... imprisoned and he is still there, and he died there. He died in those chains of imprisonment there.' Secondly, residents in the married quarters complained bitterly about the limited size of homes as the quarters made 'no provision for the sleeping of families.' Even the most basic facilities for cleanliness were lacking: single taps were often quite far from homes and, moreover, served several blocks of homes. ${ }^{92}$ Thirdly, the lines of command established by the local state, where the township superintendent had full authority, were such as to undermine the ideal of the respectable household in which the male head provided familial security. One Langa resident remembered this loss of authority in bitter detail:

being a married man residing in my own house I have got my own things, my own belongings, and as a man with a wife I see the assistant native Superintendent appearing in my doors saying that I must go to the barracks. What about my property? I am told I shall vacate my house. Where am I go to, to any special quarters in these little rooms it is not enough. No, you can sell or dispose of the property. It is one of the chief points which grieves

\footnotetext{
${ }^{88}$ Native Economic Commission, Evidence of Dr. T. Shadick Higgins, vol. 4, Cape Town, 28 April 1931; CA 3/CT 4/1/9/1/7, Report of P.G. Caudwell, Inspector of Urban Locations, 30 April 1941.

${ }^{89}$ CA 3/CT 4/1/9/1/138, S.A. Rogers - Secretary, Labour Consultative Committee, Cape Town, 21 Aug. 1957.

90 'The Langa Fiasco', Cape Argus, 1 Feb. 1928.

91 'A new township in the making', Cape Argus, 4 June 1927; 'The weak spot at Langa', Cape Argus, 7 June 1927; CA 3/CT 4/1/5/1266, Meeting at Langa, 25 Oct. 1930.

92 'Like a village of the dead', Cape Argus, 27 Sep. 1930.
} 
This is the accepted version of an article that will be published by Cambridge University Press in The Journal of African History: https://www.cambridge.org/core/journals/journal-of-african-history/allissues

Accepted version downloaded from SOAS Research Online: http://eprints.soas.ac.uk/25963/

us in this village. If a man is able to stand and pay these rents in full why is he not entitled to stay and remain where he is supposed to remain? ${ }^{93}$

Finally, and perhaps most importantly, the married quarters at Langa failed to secure the decency of marital relations. 'I have three children,' one Langa resident explained. 'One of them is in school in standard six, but how disgraceful it is when I go to bed with no privacy with the children and the mother and everybody in the same room. If I want to have a private little chat with mother the children already understand what I say to mother,' he continued in euphemistic terms. ${ }^{94}$ In Langa, respectability was clearly a victim of contradictory state policies.

It was in the development of coloured housing townships towards the end of the $1920 \mathrm{~s}$ and in the course of the 1930s that the local state had greater success in putting in place the material basis of respectability. The area of Athlone was identified as suitable for the establishment of such housing schemes, all of which were firmly based on the principle of segregation. ${ }^{95}$ The most important schemes, those at Bokmakirie and Sunnyside, were planned 'exclusively for the occupation of non-Europeans. 96

Housing developments such as the one at Bokmakirie unambiguously sought to create a respectable coloured citizenry. The township was meant to represent a transition from the 'depressing squalor' and 'dark vermin-infested hovels of the slums' to 'clean little cottages with a bit of a garden plot.' The scheme was aimed at families 'whose economic circumstances had made it previously impossible for them to escape from slum tenements.' Bokmakirie was built around two- and three-bedroomed cottages, and while only the larger ones had dedicated bathrooms, all were connected to a water-borne sewerage system. By 1933, 144 cottages had been erected. Rental costs included the supply of water and electricity. 'The tenants are selected with care,' said Margaret Hurst, Cape Town's 'Housing Manageress', a post created by the City Council as part of plan to provide 'decent homes for the respectable coloured worker.' The objective of the Bokmakirie scheme, she noted, was to

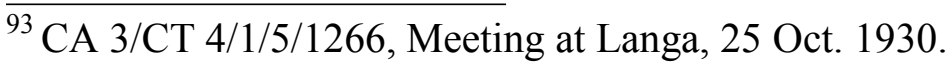

${ }^{94}$ CA 3/CT 4/1/5/1266, Meeting at Langa, 25 Oct. 1930; see also M. Musemwa, 'Aspects of the social and political history of Langa Township, Cape Town, 1927-1948', (M.A. thesis, University of Cape Town, 1993), p. 52.

${ }^{95}$ CA 3/CT 4/1/5/576, Slums Bill, 1934, Evidence to be submitted before the Parliamentary Select Committee by delegates representing the Council of the City of Cape Town; 'Klipfontein Road Scheme Rejected', Cape Argus, 28 May 1930.

96 'Non-European housing scheme', Cape Argus, 29 Dec. 1928.
} 
This is the accepted version of an article that will be published by Cambridge University Press in The Journal of African History: https://www.cambridge.org/core/journals/journal-of-african-history/allissues

Accepted version downloaded from SOAS Research Online: http://eprints.soas.ac.uk/25963/

'help the poor and deserving families. ${ }^{97}$ Thus great care was taken to interview coloured tenants who lived 'under insanitary conditions' in the city centre for their suitability to the new scheme. One such family were the Petersens, who were found in a 'clean and tidy' room for which they paid $7 \mathrm{~s} .6 \mathrm{~d}$. per week. Though they were in arrears with their rental payments, the family were identified as a 'respectable class of coloured which is deserving of consideration. ${ }^{98}$

At first glance, the planners of these townships could claim success. 'In every respect,' wrote a visitor to Cape Town, 'this little group of suburban homes for coloured residents of Cape Town presented as neat an appearance as might be expected elsewhere. Pride in ownership and maintenance was evident everywhere. Yards were carefully kept, flowers planted, and all rubbish had been burned or carted away. ${ }^{99}$ At Bokmakirie residents were said to take 'great pride in their little homes and gardens', and one observer claimed to have seen houses " "where you could eat your dinner off the floor." 100 The Wilcocks Commission heard that examples of 'clean homes' could be seen in the new housing settlements, many of the inhabitants having been 'drawn from the slum areas of Cape town. ${ }^{101}$ Most significantly, women were at the heart of this process of making respectability: 'The housewives were most hospitable,' wrote one visitor to one of the Athlone schemes, 'and everywhere we had evidence of a woman's hand and a woman's love in keeping the home attractive for the husband and children., 102

Ultimately, however, as at Langa, such attempts at making respectability proved elusive. In the first instance, the amounts of capital invested by the Cape Town City Council came nowhere close to addressing the depths of the housing crisis. Funds budgeted for housing were sometimes not spent as the City Council, heeding calls from ratepayers reluctant to spend money on black housing, sought to pass the cost to the national government. ${ }^{103}$ The upshot was that very few of these houses were built. Given the extent of the housing shortage, the number of houses in schemes such as Bokmakirie was hopelessly

\footnotetext{
97 'City's housing policy', Cape Times, 30 March 1933; 'Escape from the slums', Cape Argus, 19 June 1935.

${ }^{98}$ CA 3/CT 4/1/5/1021, Bokmakirie Township, Athlone, Reports of Medical Officer of Health re Insanitary Conditions of Dwellings in Cape Town.

99 'Suburban homes at Athlone', Cape Argus, 14 Jan. 1929.

100 'Escape from the slums', Cape Argus, 19 June 1935.

101 'Memorandum by J. de Kock', Evidence presented to Wilcocks Commission, 29 March 1935.

102 'Suburban homes at Athlone', Cape Argus, 14 Jan. 1929.

103 '200 Years to rid city of slums', Cape Argus, 22 Feb. 1935; 'Move to speed up city housing schemes', Cape Argus, 27 Feb. 1935.
} 
This is the accepted version of an article that will be published by Cambridge University Press in The Journal of African History: https://www.cambridge.org/core/journals/journal-of-african-history/allissues

Accepted version downloaded from SOAS Research Online: http://eprints.soas.ac.uk/25963/

inadequate. A parliamentary select committee heard that the township 'made no apparent impression on slum reduction. ${ }^{, 104}$ Secondly, and as a consequence of council and government underinvestment, the cost of these schemes had largely to be borne by tenants and prospective home-owners themselves. Thus houses were affordable only to 'fairly well-paid coloured families. ${ }^{, 105}$ In reality, only semi-skilled workers in regular employ could even contemplate applying for these homes. ${ }^{106}$ In the early days of the Sunnyside scheme, prospective occupants made barely a dozen housing applications for the simple reason that cost was beyond the incomes of the vast number of would-be applicants. Unlike Bokmakirie, the scheme at Sunnyside was based on the principle of home-ownership. Here, houses ranging in price from $£ 223$ to $£ 451$ could be bought on hire-purchase agreements extending over a twenty-year period. Each of the houses contained a living room, kitchen, shower, lavatory, and at least two bedrooms. Under such schemes 'thrifty coloured folk' were given 'a chance of becoming their own landlords,' the Cape Argus wrote somewhat victoriously. ${ }^{107}$ But the monthly cost of $£ 2.5 .0$ was too high for those in need, the majority of whom earned less than $£ 2$ per week. ${ }^{108}$

Perhaps most importantly, there was no guarantee that respectability, once attained, could be nourished, for it remained fragile during times of such great economic uncertainty. It was reported in 1933, for example, that 78 out of the 452 cottages at Gleemor and Sunnyside had been surrendered, and that the Depression had put an end to further housing construction. ${ }^{109}$ Bokmakirie struggled to retain the facade of respectability. Numerous tenants soon fell into arrears with their rental payments. ${ }^{110}$ One such person, C.M. Essack, was reported to be 'a bad payer' from the time of his arrival in the scheme and ran up arrears of $£ 5.7 .9{ }^{111}$ The ideal of a pretty cottage inhabited by a nuclear family was quickly undermined as numerous residents erected wood and iron structures in their backyards, no doubt to accommodate extended family members or lodgers. ${ }^{112}$ The scheme's caretaker had to work hard at maintaining cleanliness: those who failed to meet acceptable standards were reported

${ }^{104}$ CA 3/CT 4/1/5/576, Slums Bill, 1934, Evidence submitted before the parliamentary select committee by delegates representing the Council of the City of Cape Town.

105 'Suburban homes at Athlone', Cape Argus, 14 Jan. 1929.

106 'Tackling the slums', Cape Argus, 31 May 1929.

107 'How slums are made', Cape Argus, 17 April 1926.

108 'City housing plan at standstill', Cape Argus, 23 Feb. 1929.

109 'City's housing policy', Cape Times, 30 March 1933.

${ }^{110}$ CA 3/CT 4/1/5/1042, Bokmakirie Caretaker - Town Clerk, Reports on tenants who are in arrears with rents by more than $£ 1,11$ Aug. 1933.

${ }_{111}$ CA 3/CT 4/1/5/1042, Bokmakirie Caretaker's Report for week ending 9 Dec. 1933.

${ }^{112}$ CA 3/CT 4/1/5/1021, Town Clerk - 33 Bokmakirie residents, 7 Sep. 1932. 
This is the accepted version of an article that will be published by Cambridge University Press in The Journal of African History: https://www.cambridge.org/core/journals/journal-of-african-history/allissues

Accepted version downloaded from SOAS Research Online: http://eprints.soas.ac.uk/25963/

to the City Council, while numerous tenants were ordered to colour wash their cottages. ${ }^{113}$ Ultimately, at housing schemes such as Bokmakirie, as well as the new location of Langa, respectability as imposed from above failed to sink deep roots.

\section{Respectability from below}

And yet, despite abundant evidence of respectability not having been attained, observers were nevertheless struck by the prevalence of respectable living among Cape Town's very poor. Even in the face of great poverty, one social worker noted, Cape Town's black population 'put up a hard fight to maintain respectability. ${ }^{114}$ On the face of it, such struggles for respectability met with a measure of success. 'It is an amazing fact,' noted the Cape Times of the city's coloured population, 'that by far the majority of the people living in these conditions [of poor housing] are decent, homely folk. ${ }^{115}$ One visitor to a number of 'wretched homes' was impressed 'not by people's dirtiness, but by their marvellous cleanliness.' Here, women managed to keep exceptionally crowded homes 'decent and even dainty.' 116 ،"In spite of appalling overcrowding and all the misery which it entails, in spite of great poverty, ignorance and sickness,"” the Marion Institute declared in similar vein, "'there are many coloured people who succeed in maintaining respectable and comfortable homes, and who send their children clean and neatly dressed to school or work every day." At the heart of such success, unsurprisingly, was the 'coloured woman' who had triumphed 'over her environment. 117

From the early 1930s, Cape Town's white bourgeoisie claimed similar success for the African township of Langa. With their eyes firmly fixed on the married quarters, observers argued that Langa's appearance was

more suggestive of a garden village than a native location. Trim houses set among rows of pine trees and wattle bushes, an airy hospital with gardens attached, welldesigned churches, and a magnificent sports ground make the area a pleasant one. Most of the native residents take considerable interest in their homes, and well-kept

${ }^{113}$ CA 3/CT 4/1/5/1042, Bokmakirie Caretaker's Report for weeks ending 9 Dec. 1933, 29 Oct. 1933; 1 Oct. 1933; 10 Sep. 1933.

114 'Plight of the city's poor', Cape Argus, 13 July 1935.

115 'Clean up Cape Town's plague spots', Cape Times, 2 Sep. 1933.

116 'Homes at 7/- a week', Cape Argus, 25 July 1929.

117 'Work of the Marion Institute', Cape Argus, 12 March 1930. 
This is the accepted version of an article that will be published by Cambridge University Press in The Journal of African History: https://www.cambridge.org/core/journals/journal-of-african-history/allissues

Accepted version downloaded from SOAS Research Online: http://eprints.soas.ac.uk/25963/

flower pots and small vegetable gardens bear witness to the "house pride" feeling which is a feature of the location. ${ }^{118}$

Such struggles for respectability among the city's black population took various forms, but the acquisition of domestic material possessions was one of the most visible routes, a trend Cape Town shared with other urban centres in the Union. 'Shopkeepers admit that the natives' custom is no longer a negligible factor,' a correspondent from Johannesburg told readers of the Cape Argus in 1924. 'One hears that not only in the matter of clothing and personal adornment, but in such accessories as scent, soaps and other toilet requisites, the natives have for some time past been closely following the most exensive European tastes ... Their domestic requirements are also increasing. ${ }^{, 19}$ Furniture especially was prized. ${ }^{120}$ These purchases were made possible by the extension of hire-purchase agreements, a practice of which sympathetic white observers disapproved. ${ }^{121}$ At N'dabeni, some homes were adorned with sewing machines, gramophones, organs, and even pianos. ${ }^{122}$ One visitor to Langa found that some of the dwellings contained furniture in 'all states of repair. ${ }^{123}$ These included gramaphones, hallstands, suites, and settees. One of the reasons for resistance to the new Langa location was that houses there were thought to be 'even too small for those who have risen so far in the scale of civilisation as to possess furniture. ${ }^{, 124}$ Once in Langa, residents complained about the fact that the houses had earthen floors: 'they want to have wooden floors, so as to be able to put in their good furniture,' noted one witness to the Native Economic Commission. ${ }^{125}$ The loss of furniture to debt collectors and second-hand dealers was a constant threat, and it took some determination on the part of families to resist surrendering their acquisitions during hard times. ${ }^{126}$

The counterpoint to this vision of respectable living was that of a rampant black criminal, or 'skolly', class. As a bourgeois version of respectability so evidently failed to sink

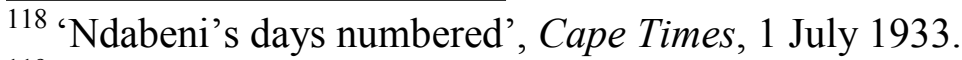

119 'Native followers of European fashions', Cape Argus, 15 Nov. 1924; W. Beinart, Twentieth-century South Africa (Oxford, 1994), p. 193.

${ }^{120}$ CA 3/CT 4/1/9/1/8, Smit Committee Report, 1941.

${ }^{121}$ Native Economic Commission, Cape Town, Evidence of Rev. Charles Savage, Cape Town, vol. 4, 25 April 1931.

${ }^{122}$ Native Economic Commission, Cape Town, Statement by Mr. G.P. Cook, Cape Town, vol. 4, 24 April 1931.

123 'Langa township toured', Cape Argus, 11 Jan. 1929.

124 'Like a village of the dead', Cape Argus, 27 Sep. 1930.

${ }^{125}$ Native Economic Commission, Evidence of T. Shadick Higgins, Cape Town, vol.4, 28 April 1931.

126 'When the last penny has been spent', Cape Argus, 29 July 1929.
} 
This is the accepted version of an article that will be published by Cambridge University Press in The Journal of African History: https://www.cambridge.org/core/journals/journal-of-african-history/allissues

Accepted version downloaded from SOAS Research Online: http://eprints.soas.ac.uk/25963/

its roots among the majority of the city's black population, even in the housing schemes at Athlone where the initial shoots were so promising, Cape Town's white middle classes perhaps inevitably perceived a growth in black criminality. Although there had been periodic concerns with crime since the beginning of the twentieth century, and even earlier, agitation became ever more frantic during the 1920 s and 1930s. ${ }^{127}$ African migrants to Cape Town were certainly seen to represent a criminal danger; the neighbourhood of Windermere, for example, was said to 'exist outside the law.' Here, the Cape Argus claimed in 1930, more 'stabbing affrays' were reported than for any other part of Cape Town, and more 'sin to the square mile' existed 'than in any other place in South Africa. ${ }^{128}$ However, almost all attention fell upon 'skollies', young coloured men and boys who had coalesced into organised criminal gangs. ${ }^{129}$ Commenting on the countrywide increase in crime for the year 1924, The Argus found that the 'outstanding feature' of the official record was the 'steady increase in the number of native and coloured persons who have adopted crime as a profession.' More specifically, 'a regular coloured criminal type' was believed to be responsible for most committed crime. ${ }^{130}$

By the mid-1930s, Cape Town's bourgeoisie saw themselves as facing a full-blown 'skolly menace'. ${ }^{131}$ During 1929 the city's records showed an increase in all serious crime except rape: the total number of criminal cases dealt with in local courts increased from 19,376 in 1929 to 19,843 the following year. Cape Town police investigated more than a thousand burglaries of houses and local businesses in the course of $1930 .{ }^{132}$ A notable increase of juvenile crime among coloured boys was recorded at the same time. ${ }^{133}$ Newspapers spoke of a 'coloured underworld' whose members were of the 'hooligan element' and for whom knives were the weapons of choice. ${ }^{134}$ Approximately 300 cases of

\footnotetext{
${ }^{127}$ Bickford-Smith et al, Cape Town in the twentieth century, p. 39.

128 'Haunt for Cape Town's criminals', Cape Argus, 8 March 1930.

129 "'No epidemic of crime", Cape Argus, 14 Nov. 1922; 'The native influx', Cape Argus, 1 Aug. 1923; 'Increase in crime', Cape Argus, 24 June 1926; 'Wave of burglary in Cape Town', Cape Argus, 19 Nov. 1930. These developments are most vividly analysed in D. Pinnock, The Brotherhoods: street gangs and state control in Cape Town (Cape Town, 1984).

130 'Increase in crime', Cape Argus, 24 June 1926.

${ }^{131}$ For example, 'The causes of the skolly menace', Cape Argus, 10 Aug. 1937.

132 'Wave of burglary in Cape Town', Cape Argus, 19 Nov. 1930.

133 'Increased crime in Cape Town', Cape Argus, 22 Jan. 1931.

${ }^{134}$ Wits Historical Papers, SAIRR AD843 B52.3, Proceedings of a Departmental committee of inquiry into the alleged increase of serious crime in the Cape Peninsula, 20 Dec. 1943; O.D. Wollheim, 'The Cape skolly', Race Relations, 17, 1950, p. 47; 'The knife', Cape Argus, 26 June 1935.
} 
This is the accepted version of an article that will be published by Cambridge University Press in The Journal of African History: https://www.cambridge.org/core/journals/journal-of-african-history/allissues

Accepted version downloaded from SOAS Research Online: http://eprints.soas.ac.uk/25963/

violent assault were heard in city-centre magistrates' courts during the first half of $1933 .{ }^{135}$ Much criminal activity was centred on the sale and consumption of dagga [marijuana] and the operation of shebeens, private homes where liquor was sold illegally. ${ }^{136}$ Despite high numbers of prosecutions involving dagga - 544 were brought before local courts in July 1929 alone - consumption of the drug remained widespread. In 1935 one magistrate guessed that 'fully 50 percent of Cape coloureds are dagga-smokers. ${ }^{137}$ Although the penalties for possession of and dealing in dagga could be substantial - offenders faced fines as high as $£ 100$ and six-month prison sentences with hard labour - police made little headway in stamping out the trade. ${ }^{138}$ Similarly, shebeens were seen as being at the heart of Cape Town's 'underworld of vice': these had a long history in the city going back to the nineteenth century, became especially well established in neighbourhoods such as District Six, and were thought to have increased sixfold in the two years leading up to 1933. A dense web of community solidarities protected shebeen-keepers against police raids. There can certainly be little doubt that the sale and consumption of vast quantities of alcohol fuelled a great deal of violence; not infrequently, shebeen quarrels resulted in the loss of life. ${ }^{139}$

Sympathetic observers attributed the increase in crime to the general form that poverty took among Cape Town's coloured population: poor housing, overcrowding, racial discrimination in the workplace, low wages, unemployment, and limited educational opportunities. ${ }^{140}$ The first of these, poor housing, argued the Cape Times, resulted in

\footnotetext{
135 'Gang warfare in the city', Cape Times, 28 July 1933.

136 'District Six crime revelations', Cape Times, 21 Feb. 1933; 'How the Iron gang operates', Cape Times, 25 Feb. 1933; 'Raiding the dope sellers of Cape Town', Cape Argus, 16 Oct. 1926; 'Room awash with kafir beer', Cape Argus, 26 Oct. 1926; 'Dagga traffic on the increase', Cape Argus, 29 Aug. 1928.

137 'Dagga traffic on the increase’, Cape Argus, 29 June 1928; '£600 dagga fire’, Cape Argus, 20 April 1935; 'Story of dagga patch on farm', Cape Argus, 27 Feb. 1935; Wits Historical Papers, SAIRR AD843 B52.3, Proceeding of a Departmental Committee of Inquiry appointed to inquire into the alleged increase of serious crime in the Cape Peninsula, 20 Dec. 1943, Evidence of Robert Hoedemaker; 'Possession of dagga', Cape Argus, 19 Oct. 1935; UG.31-'52, Report of the Inter-Departmental Committee on the Abuse of Dagga, p. 6; Bickford-Smith et al, Cape Town in the twentieth century, p. 105.

138 'Dagga traffic on the increase', Cape Argus, 29 June 1928; ' $£ 600$ dagga fire’, Cape Argus, 20 April 1935.

139 'Crime in Union's liquor dens', Cape Argus, 21 May 1926; 'Raiding the dope sellers of Cape Town', Cape Argus, 16 Oct. 1926; 'Room awash with Kafir beer', Cape Argus, 26 Oct. 1926; 'District Six crime revelations', Cape Argus, 21 Feb. 1933; 'Peninsula riddled with shebeens', Cape Argus, 22 April 1944.

${ }^{140}$ Wits Historical Papers, SAIRR AD843 B52.3, Proceedings of a Departmental Committee of Inquiry into the alleged increase of serious crime in the Cape Peninsula, 20 Dec. 1943, See especially evidence of Sam Kahn and Betty Sacks.
} 
This is the accepted version of an article that will be published by Cambridge University Press in The Journal of African History: https://www.cambridge.org/core/journals/journal-of-african-history/allissues

Accepted version downloaded from SOAS Research Online: http://eprints.soas.ac.uk/25963/

'lawlessness and vice' taking a 'grip on the youthful coloured mind.' '141 'I am certain,' argued one magistrate, 'that healthy housing - ordinary, clean, housing - would have saved many a youth from being inoculated with a virus which had led to his becoming a charge upon the criminal administration of the State. ${ }^{142}$ More fundamentally, however, the underlying cause of the 'skolly problem' and black criminality more generally was seen to be the result of the failure among the majority of Cape Town's black population to realise the idealised respectable household. One manifestation of this was a loss of authority of parents over children. ${ }^{143}$ Specifically, crime and juvenile delinquency were manifestations of what many perceived to be the failure of coloured women to fulfil their role as 'home-makers.' The same poverty that drives the poor to the slum,' wrote Sydney Lavis, 'compels the mother to eke out the family income by outside employment.' Despite considerable effort in the struggle against poverty, women 'inevitably lost the fight. ${ }^{144}$ Forced into the labour market as a result of the inadequate earnings of men, so the argument went, coloured women neglected their "natural" role as mothers. ${ }^{145}$ They had "neither the time nor the energy for wage-earning as well as homemaking,' concluded the Wilcocks Commission. ${ }^{146}$ Thus juvenile delinquents were said to come from homes where there was 'no cleanliness ... no order and no discipline. ${ }^{147}$ Put in another way, they came from homes that were not respectable.

These contradictory and alternating visions of respectability among Cape Town's black population - as being thoroughly unattainable under conditions of great poverty, yet present at the same time - require explanation. Contemporary observers resolved the apparent contradiction by seeing respectability as the achievement of the black elite, or what contemporary observers called the 'better off' or 'superior class. ${ }^{148}$ It was clear, however, that the social and economic gulf between the black elite and the very poor was not nearly as deep as bourgeois observers made out. It has to be remembered, firstly, that the black elite constituted a very small and fragile class. Made up of artisans, traders, clerks, teachers and other professionals, no more than 5 percent of the coloured population could be considered

\footnotetext{
141 'Clean up Cape Town's plague spots', Cape Times, 2 Sep. 1933.

142 'Crime due to the bad housing', Cape Argus, 7 Aug. 1925.

${ }^{143}$ CA 1/CT 420, 20/8/12, Probation Officer's Monthly Report, 29 March 1935.

144 'The hell in which the coloured man lives,' The Sun, 8 July 1938.

${ }^{145}$ Wilcocks Commission Evidence, Memorandum by J. De Kock, 29 March 1935.

${ }^{146}$ UG. 54-'37, Wilcocks Commission Report, p. 19.

${ }^{147}$ Wilcocks Commission Evidence, Memorandum by Josep de Kock, 29 March 1935.

${ }^{148}$ CA 1/CT 420, 20/8/2, Probation Officer’s Monthly Report, 29 March 1935.
} 
This is the accepted version of an article that will be published by Cambridge University Press in The Journal of African History: https://www.cambridge.org/core/journals/journal-of-african-history/allissues

Accepted version downloaded from SOAS Research Online: http://eprints.soas.ac.uk/25963/

members of an elite class at the beginning of the twentieth century. ${ }^{149}$ Under conditions where educational provision was almost wholly confined to poorly funded and inadequate church schools, it was difficult for this class to significantly increase their numbers. As was the case for the Union as a whole, Cape Town's African elite was a similarly small class of people. The 1911 census counted less than half of one percent of the country's African workforce (11, 673 people) as 'professional,' while 20,786 were listed as being engaged in 'commercial occupations.' Ten years later, 'professional', 'technical' and related occupations (including teachers) constituted 0.7 per cent of the working population. ${ }^{150}$ The Native Economic Commission heard that only about 56 percent of children of schoolgoing age in Langa and N'dabeni were at school. Schooling for boys and girls in these townships was offered only up to Standard VI, the first year of secondary school. ${ }^{151}$ It was only with great sacrifice that some African parents in Cape Town were able to send their children to Lovedale, the first and most important of South Africa's 'native training institutions., 152

Secondly, the numerical weakness of Cape Town's black elite was underlined by the fact that members of this class lacked the material means to physically distance themselves from the rest of the poor. The planners of the township at Langa were from the start keen to separate the very poor from the 'better type of native who wishes to have a room of his own or to share one with a mate.' Thus special quarters for single men were built a little distance from the main barracks with 'little touches' to give them 'a certain superiority. ${ }^{153}$ Little came of these plans however; as Muchaparara Musemwa has noted, the City Council's overriding concern to enforce residential segregation "tended to obliterate the "class divisions" among Africans at Langa. ${ }^{154}$ Those who chose not to live in Langa were hardly better off. In 1931 members of the Native Economic Commission found registered African voters, "natives ... of the better class', living under appalling conditions in the city centre. ${ }^{155}$

\footnotetext{
${ }^{149}$ Adhikari, "The product of civilisation in its most repellent manifestation", pp. 287, 290; Lewis, Between the wire and the wall, p. 12; Bickford-Smith et al, Cape Town in the twentieth century, p. 38.

${ }^{150}$ Cobley, Class and Consciousness, pp. 39, 43, 61; Report of the Third Census of the Population of the Union, Part X, 3 May 1921.

${ }^{151}$ Native Economic Commission Evidence, Evidence of Baronson Walton Mama, 25 April 1931; Evidence of G.P. Cook, 24 April 1931.

152 'Needs of natives at Langa', Cape Argus, 17 Aug. 1925.

153 'A new township in the making', Cape Argus, 4 June 1927; Musemwa, 'Aspects of the social and political history of Langa Township', pp. 36-38.

${ }^{154}$ Musemwa, 'Aspects of the social and political history of Langa Township, Cape Town, 1927-1948', p. 167.

155 'Economic Commission visits slums', Cape Times, 29 April 1931.
} 
This is the accepted version of an article that will be published by Cambridge University Press in The Journal of African History: https://www.cambridge.org/core/journals/journal-of-african-history/allissues

Accepted version downloaded from SOAS Research Online: http://eprints.soas.ac.uk/25963/

The same was true for coloured households. During the interwar years those who had managed to acquire professional qualifications received pitiable salaries. For example, male and female coloured schoolteachers, probably the most likely recruits to the halls of respectability, typically earned less than coloured workmen and found that their salaries approximated those of unskilled workers, while skilled coloured women could earn more than female schoolteachers. ${ }^{156}$ The consequence of such circumstances was that those who passed the bar of respectability were only a small distance from those who did not, and movement from one category to the other could be in either direction. 'We still have families - decent and respectable families - eking out an existence in homes, so called, which are totally unworthy of them,' the Cape Argus noted in $1929 .{ }^{157}$ One such example was that of a city-centre home occupied by a man, a child, and a "superior"” woman. The home comprised no more than a windowless, unventilated single room on the upper floor of a house with a leaking roof; a "rough crowd"" occupied the rooms below. Despite the wretchedness of their surroundings, the family had managed to accumulate two beds, a wardrobe with glass panels, a dressing table, and even a harmonium. ${ }^{158}$ This was a clear quest for respectability, but one quite obviously pursued by people who were very poor. In short, and as Mohamed Adhikari has pointed out, 'there was no great social distance between the coloured petty bourgeoisie and the coloured labouring poor. ${ }^{, 159}$ Familial ties and the shared language of Afrikaans bound the two categories, the coloured petty bourgeoisie's preference for English notwithstanding. Dr. Abdullah Abdurahman, leader of the African Political Organisation (APO) from 19051940, personified these bonds. ${ }^{160}$

Thirdly, and perhaps most importantly, the gap between respectability and what appeared to be its most visible antithesis, 'skollydom,' could be easily breached. In the absence of parental supervision, children were frequently drawn to youth gangs 'always on the lookout for a respectable type of boy to increase the ranks of the gang. ${ }^{, 161}$ Although most white observers were probably oblivious to the finer gradations within coloured society, it is

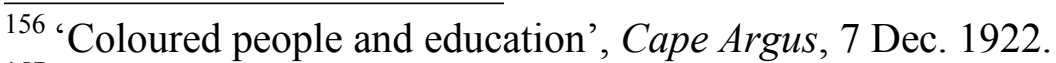

157 'Housing week', Cape Argus, 3 June 1929.

158 'Scandal of Cape Town's slums', Cape Argus, 27 June 1929.

${ }^{159}$ Adhikari, “The product of civilisation in its most repellent manifestation”, p. 288.

${ }^{160}$ Ibid, pp. 287-89.

${ }^{161}$ Wits Historical Papers, SAIRR AD843 B52.3, Proceedings of a Departmental Committee of Inquiry into the alleged increase of serious crime in the Cape Peninsula, 20 Dec. 1943, Evidence of Robert Hoedemaker.
} 
This is the accepted version of an article that will be published by Cambridge University Press in The Journal of African History: https://www.cambridge.org/core/journals/journal-of-african-history/allissues

Accepted version downloaded from SOAS Research Online: http://eprints.soas.ac.uk/25963/

nevertheless instructive that 'the [white] public did not seem to be able to separate the skolly from the hard working man., 162

Not only was there little to separate the respectable from the non-respectable, the two categories all too often occupied the same household. Sydney Lavis described this phenomenon most vividly:

A diagnosis of the ['skolly menace'] starts with the fact that there are no skolly families in Cape Town ... [Here] a skolly boy often means a father and mother dreadfully poor, living in a slum room, but decent God-fearing folk, and very likely grown-up brothers and sisters of respectable character working hard for a living all of whom live under a cloud of constant shame and sorry because of the black sheep of the family. ${ }^{163}$

Such powerful sentiments were echoed in the records of criminal cases. In 1930, for example, a number of young boys, ranging in age from 12 to 17, were brought before a Cape Town magistrate on charges involving burglary and theft. The records are most revealing of the porousness of the boundaries that separated youth criminality from respectability. The city's Probation Officer found that the boys' home conditions were 'fairly satisfactory.' One of the accused, Achmat Salie, lived with his parents and siblings in a 'fairly clean' District Six house and attended Trafalgar High School, one of the better schools for coloured children and alma mater of notable political figures of the period. Here, one of his teachers found him to be 'of good character and promising.' For five years prior to this case, Achmat spent his evenings having religious instruction at his local mosque; the imam there swore that his behaviour had 'always been beyond reproach.' In sum, the court's own investigations into the boys' lives found much evidence of respectability. And yet, as if to find a hard distinction with criminality and to justify the criminal sentences that would inevitably follow, the Probation Officer concluded that none of the boys were 'under proper control' and that they were 'in need of stricter discipline than any of the parents could possibly exercise.' The judicial outcome was thus predictable: most were sentenced to spells of detention in the city's main reformatory at Tokai, while some were subjected to corporal punishment. ${ }^{164}$ Magistrate Willshire Harmer may have believed that conditions at the Tokai Reformatory were 'healthy

\footnotetext{
$\overline{162}$ Wits Historical Papers, SAIRR AD843 B52.3, Proceedings of a Departmental committee of inquiry to inquire into the alleged increase of serious crime in the Cape Peninsula, Evidence of Major Claude Myles, 20 Dec. 1943.

163 'The Cape Town skolly menace', The Sun, 20 Aug. 1937.

${ }^{164}$ CA CSC 1/3/1/15, Appeal in criminal case of Achmat Salie, 10 Oct. 1930; M. Adhikari, Not white enough, not black enough: racial identity in the South African coloured community (Cape Town, 2006), p. 117.
} 
This is the accepted version of an article that will be published by Cambridge University Press in The Journal of African History: https://www.cambridge.org/core/journals/journal-of-african-history/allissues

Accepted version downloaded from SOAS Research Online: http://eprints.soas.ac.uk/25963/

and good' and such as to turn boys into 'useful citizens,' but the institution was 'truly a school of criminality., 165

Under these circumstances, and in a city with its roots in slavery and colonial dispossession, a significant section of the coloured population sought respectability by emphasising racial difference. Since the early years of the twentieth century, and especially following the 'hooligan riots' of 1904, the pursuit of respectability among members of the coloured elite also meant the promotion of an exclusive coloured ethnicity. ${ }^{166}$ This became even more pronounced, and taken up by a broader section of the coloured population, as the housing crisis deepened during the interwar years. Ratepayers' associations became one of the most important vehicles for agitation in favour of influx control and residential segregation. In the late 1920s, for example, the Kensington Ratepayers Association began a campaign on behalf of what they believed to be the 'respectable and civilised class' of residents against the African presence in the broader Kensington/Windermere area. 'I thought the Council made Langa for the natives,' noted a resident of the area, clearly resentful at Africans' successful resistance to being pressed into the new township. ${ }^{167}$ Despite persistent persecution, however, Africans remained in Windermere, and it was only the apartheid state's brutal efforts of the 1950s that finally destroyed the African community there. By 1956 at least two-thirds of the 6,000 residents of new hostels in Langa were men who had been forcibly removed from Windermere. In July 1959 the entire area was declared a coloured 'group area' in line with the Group Areas Act (1950), a decision that would no doubt have brought joy to the Kensington Ratepayer' Association. ${ }^{168}$ But the pursuit of respectability in racial difference was a futile quest, for, until such time that apartheid completed what segregation had started, Windermere had 'a little bit of everything,' where 'perfectly cleanlooking houses' were 'less than a stone's throw from ... filth, want and squalor.' 169 'There is prosperity and respectability and there is crime, poverty and vice ... All things are possible,' concluded an investigation of the Cape Argus into the 'different types of life on the Cape Flats. $^{, 170}$

\footnotetext{
${ }^{165}$ Iliffe, African Poor, pp. 137-38.

${ }^{166}$ Bickford-Smith et al, Cape Town in the twentieth century, p. 43.

${ }^{167}$ CA 4/CT 4/1/71, Letter from Medical Officer of Health - Sanitary Inspector E. Hadley, 16 July 1934, enclosing letter from 'Inhabitants' of the Kensington Estate, 15 July 1934; B. Kinkead-Weekes, 'Africans in Cape Town: state policy and popular resistance, 1936-73', (Ph.D thesis, University of Cape Town, 1992), p. 14.

${ }^{168}$ Kinkead-Weekes, 'Africans in Cape Town', pp. 338-45.

169 'Among the wilds at Windermere,' Cape Argus, 9 Aug. 1930.

170 'Crime menace on the Cape Flats', Cape Argus, 9 Sep. 1930.
} 
This is the accepted version of an article that will be published by Cambridge University Press in The Journal of African History: https://www.cambridge.org/core/journals/journal-of-african-history/allissues

Accepted version downloaded from SOAS Research Online: http://eprints.soas.ac.uk/25963/

\section{Conclusion}

Low wages, unemployment, limited education, poor housing, dreadful overcrowding, ill health, and shortened lifespans were the hallmarks of poverty endured by Cape Town's black population during the era of segregation. Each of these factors stood in the way of respectability.

In the hope of establishing a stable and docile black citizenry, the state responded to these circumstances by seeking to impose respectability from above. But in the African 'locations' such as N'dabeni and Langa, state-imposed respectability floundered. This version of respectability, predicated upon the principle of 'influx control' and the construction of townships for the sole occupation of single men, failed to take root. One of the reasons for the failure was that Africans resented having their domestic arrangements decided for them. In coloured townships such as Bokmakirie, respectability from above initially appeared to bear fruit, as residents took to living in idealised, clean, and nuclear households. But this was a very fragile respectability, quickly strangled by encroaching poverty.

By contrast, it was respectability as constituted from below, by the poor themselves, which was most enduring. For respectability was about earning the respect of one's peers, and in this regard Cape Town's poor were no different from those further up the economic ladder. Certainly, the poor could not simply replicate the respectability of the dominant white bourgeoisie, for the gulf that separated the respective beneficiaries and victims of stateenforced segregation was too wide. But it was in and among the dwellings of the mass of Cape Town's poor black population that respectability was more actively pursued than anywhere else. Ironically, it was also here that respectability was most invisible to contemporary white observers in search of the version with which they were familiar; with rare exceptions, they found a version that they could neither understand nor recognise. To be sure, the poor showed attachment to values that would have been recognisable to the city's dominant class. Cleanliness was perhaps first among these, despite coming at a very high price, but other elements of intimate life, such as the widespread prevalence of conception out of wedlock, were incompatible with bourgeois understandings of respectability. Most starkly, widespread criminality was not merely deemed to be lacking in respectability, but offered a direct challenge to the established order. And yet, 'skollydom', far from being the 
This is the accepted version of an article that will be published by Cambridge University Press in The Journal of African History: https://www.cambridge.org/core/journals/journal-of-african-history/allissues

Accepted version downloaded from SOAS Research Online: http://eprints.soas.ac.uk/25963/

antithesis of respectability, as the city's bourgeoisie argued time and again, was built into the fabric of daily life among the poor. Unable to earn respect, 'skollies' demanded it from those around them, most often by violent means. It was not simply that the housing crisis ensured that the poor and small black elite lived side by side, occupying the same neighbourhoods and streets, but that 'skollies' lived in households that may have been respectable in every other way. For this was a respectability that was fragile, elusive, and riddled with contradictions, the consequences of adaptation to great poverty. 